\title{
人工股関節全置換術および人工骨頭置換術に
} おける再手術例の検討

\author{
九州厚生年金病院整形外科 \\ 松 永 大 助 $・$ 上 崎 典 雄 \\ 村上陽太郎・西 崎 博 巳 \\ 西田民夫・松本直之 \\ 池田正一・緑川孝二 \\ 井上尚 美
}

\section{A Clinical Study of Revision in Total Hip Replacement and Universal Hip Replacement}

by

\author{
Daisuke Matsunaga, Norio Uezaki, Yōtaro Murakami, \\ Hiromi Nishizaki, Tamio Nishida, Naoyuki Matsumoto, \\ Shōichi Ikeda, Koji Midorikawa and Hisayoshi Inoue \\ Department of Orthopedic Surgery \\ Kyushu-Koseinenkin Hospital
}

Revision total and universal hip replacement has become a major important problem.

In this present study, 10 hips of 9 patients with THR and 11 hips of 11 patients with UHR underwent revision arthroplasty during the period from 1980 to 1985. Except for 2 cases of infection, the most common causes for revision arthroplasty in THR and UHR were femoral component loosening (resulting from technical failure and incongruity of the stem) and central migration respectively.

Revision arthroplasty was performed by cementless prosthesis of the bipolar type and corticospongious bone grafting to provide bone stock. Results were considered satisfactory.

\section{は じめに}

全人工股関節置換術 (以下 THR) および人工骨頭置 換術 (以下 UHR) は各種股関節疾患に対し, 除痛効果, 関節機能温存をもたらし，その有効性が広く認められ ている反面, 感染や力学的生物学的要因による合併症 など大きな問題となっている. 今回われわれは昭和 55 年より当院にて行われた THR および UHR 再手術例の 原因，問題点，再手術術式などにつき検討を加えたの で報告する。

\section{対象および方法}

症例は, THR が 9 症例, 10 関節, 初回手術時平均年 令 51 才 $(25 \sim 67$ 才 $)$, 原疾患としては変股症 5 関節,
RA 3 関節, 結核性股関節炎 1 関節, 外傷性股関節症 1 関節。再手術までの期間平均 5 年 1 力月. 初回使用さ れた prosthesis は Charnley-Müller 6 関節, Müller 3 関節，その他 1 関節である。一方，UHR は 11 症例， 11 関節で初回手術時平均年令 59 才 (39〜81才), 原疾 患は当然のごとく大腿骨䅡部内側骨折がもつとも多く 5 関節，他は変股症，頝部骨折後の偽関節それぞれ 2 関節，額部骨折後，cobalt 照射後の骨頭壊死それぞれ 1 関節であり，再手術までの期間は平均 6 年 11 力月, 使用された prosthesis は Austin-Moore 5 関節，他は Bateman, Giliberty, Osteonics となっている(表 1)。

結果

各々につき再手術の原因を調べてみると,THR では 
表 1 初回手術々式

THR

\begin{tabular}{ll|c}
\hline Charnley-Müller & 6 \\
Müller & 3 \\
& Aufranc Turner & 1 \\
\hline & & 10 股 \\
\hline UHR & & \\
\hline \hline & Austin-Moore & 5 \\
& Giliberty & 2 \\
& Bateman & 3 \\
& Osteonics & 1 \\
\hline
\end{tabular}

\section{表 2 再手術の原因}

THR

\begin{tabular}{|c|c|}
\hline 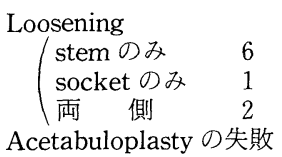 & 9股 \\
\hline & 10股 \\
\hline
\end{tabular}

UHR

\begin{tabular}{l|l}
\hline Central migration & 5 \\
Stem 側の Loosening & 2 \\
Infection & 2 \\
Acetabular failure & 1 \\
Dislocation & 1 \\
\hline
\end{tabular}

10 関節中 9 関節までが緩みであり,とくに stem 側での 緩みが 6 関節と多く, 特幑として cement-stem 間にも

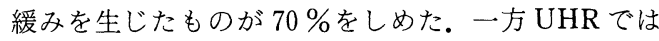
central migration がもっとも多かった（表 2 ).また， THR の緩みを来す原因であるが, stem 側では 50〜 60 \%に socket 側では約 $70 \%$ に手術手技, stem 選択不良 がみられ，これが主因をなしているものと思われた。 なお，その他の背景因子として，骨粗鬆症，日常活動 性のしめる割合も多く，手術手技に関係なくこれが誘 因と考えられた症例は 2 例であった(表 3 )。再手術術 式であるが, THR では骨移植併用の上, stem のみ置 換したもの 6 関節, 両側共置換したもの 2 関節, 他は, cement 使用し stem 置換したものと acetabular dee-
表 3 THR Loosening の原因及び背景因子

\begin{tabular}{|c|c|}
\hline stem 側 & 8 股 \\
\hline $\begin{array}{l}\text { stem の内反 } \\
\text { 不十分な cementing } \\
\text { Femur と stem の不適合 }\end{array}$ & $\begin{array}{l}4 \\
5 \\
5\end{array}$ \\
\hline socket 側 & 3 股 \\
\hline $\begin{array}{l}\text { setting の不良 } \\
\text { 不十分な cementing } \\
\text { 不適切な anchoring }\end{array}$ & $\begin{array}{l}2 \\
2 \\
2\end{array}$ \\
\hline その他の背景因子 & \\
\hline $\begin{array}{l}\text { 骨粗鬆症 } \\
\text { 術後の高い活動性 } \\
\text { 肥満 } \\
\text { 著明な脚長差, 動摇膝 } \\
\text { 交通事故 } \\
\text { 夫の暴力 }\end{array}$ & $\begin{array}{l}4 \\
4 \\
2 \\
1 \\
1 \\
1\end{array}$ \\
\hline
\end{tabular}

表 4 THR 再手術々式

\begin{tabular}{ll}
\hline \hline stem のみ置換 \\
$\begin{array}{l}\text { BHP Moore type (骨移植併用) } \\
\text { Charnley-Müller (cement 使用) }\end{array}$ & 6 \\
$\begin{array}{l}\text { socket のみ置換 } \\
\text { Acetabular deepening 併用 }\end{array}$ & 1 \\
$\begin{array}{l}\text { 両側置換 } \\
\text { BHP Moore type (骨移植併用) }\end{array}$ & 2 \\
\hline & 10 股 \\
\hline
\end{tabular}

表 5 UHR 再手術々式

\begin{tabular}{l|c}
\hline \hline Osteonics (骨移植併用) & 5 \\
THR (Müller, Harris) & 2 \\
BHP (cement 使用) & 1 \\
Resection arthroplasty & 2 \\
Acetabuloplasty & 1 \\
\hline & 11 股 \\
\hline
\end{tabular}

pening 併用し socket 置換したもの各 1 関節である (表 4 ). UHR は central migration 起こしたもの全例に 骨移植併用の上, Osteonicsに置換した. 感染の 2 例は 術中感染が疑われ，抜去し経過をみている(表 5 )。な お，後療法であるが骨移植併用例は，2 力月免荷，全 荷重は 3 力月より行った。

代表的症例を供覧する. 


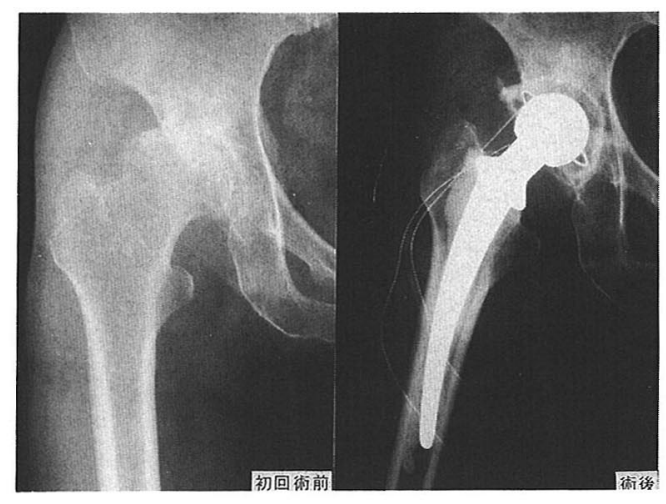

図 1 H.O., 70 才, 女性.
あるため，骨移植併用の上， trochanter plate使用し， BHP Moore typeのlong stemに置換。術中骨折を起 こしたが， 2 年 3 カ月の現在, stableな状態となってい る(図 3 )。次に問題のあった症例である.55才，女性。 右亜脱臼性変股症にて, 昭和 54 年 4 月 THR 施行 (図 4 )，4 年後の昭和 58 年, 交通事故にあい疼痛増 強。その 2 力月後の再来時レ線では stem 側の著明な緩 みと cement の折損があり, stem のみ BHP Moore type に置換したが stem 中央部にて著明な骨皮質の菲 薄がみられる，転子部での補強が必要であったと反省 させられた症例である(図 5 )。

症例 $4: 70$ 才，女性。

術後 cementing に問題がある

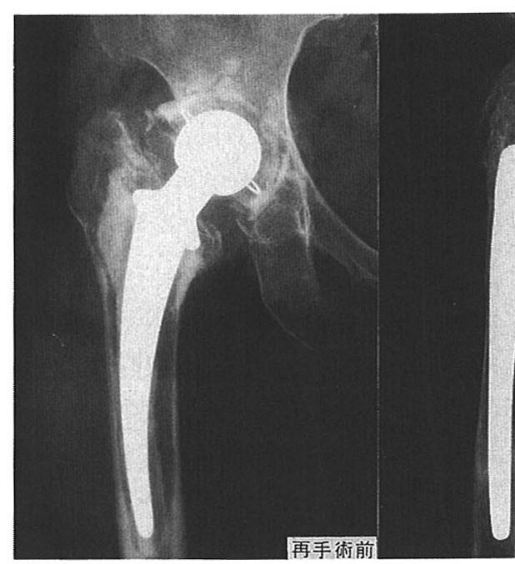

a.

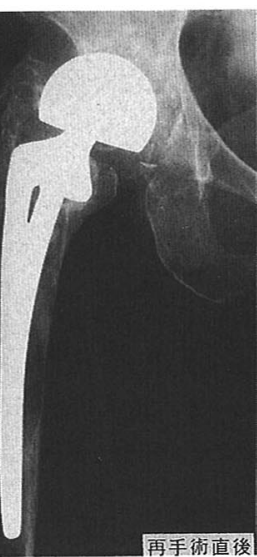

b.

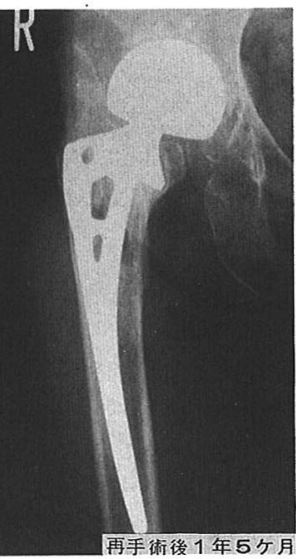

c.

図 2 H. O., 70 才, 女性.

a. 2 年 10 カ月後, 著明な loosening が，とくに stem 側にみられる

b. 骨移植併用の上, BHP Moore type stem に置換

c. 臼蓋側に反応性骨硬化像。stem 側に骨吸収. 菲薄化像の改善みられる

症例 $1: 70$ 才，女性.

右変股症にて昭和 56 年 7 月 THR 施行。術後のレ線 にて cementing に問題がある(図 1 )。1 年後より疼痛 出現. 2 年 10 力月後再来時レ線では著明な緩みが, と くに stem 側にみられる。ただちに骨移植併用の上, BHP Moore type に置換. 1 年 5 力月後の現在, 臼蓋側には 反応性骨硬化像出現し大腿側に骨吸収, 菲薄化像の改 善がみられる(図 2)。症例 2:31才, 女性。

RA. 股部痛強く歩けないということで昭和 51 年 7 月, THR 施行。手術時レ線では cementing, stem の 設置にやや難がある. 8 年後再び疼痛増強, 再来時レ 線にて著明な緩みと, calcar および小転子部の骨吸収
他医にて大腿骨䅡部骨折にて Austin-Moore 人工骨 頭置換術を受け, 17 年後, 可動域制限と疼痛のため, 当科初診。レ線にて central migration があり, 骨移植 併用の上, Osteonics type に置換した（図6).

考察

THR およびUHR の長期遠隔成績が明らかになるに つれて種々の合併症や再手術例に関する報告も次第に 増加しつつある。再手術の原因としては，THRでは stem 抒よび socket の緩み, 感染, 大腿骨骨折, 脱臼, 人工関節の折損，また，UHR では central migration などが挙げられる。とくに THRに扔いては, 緩みは成 


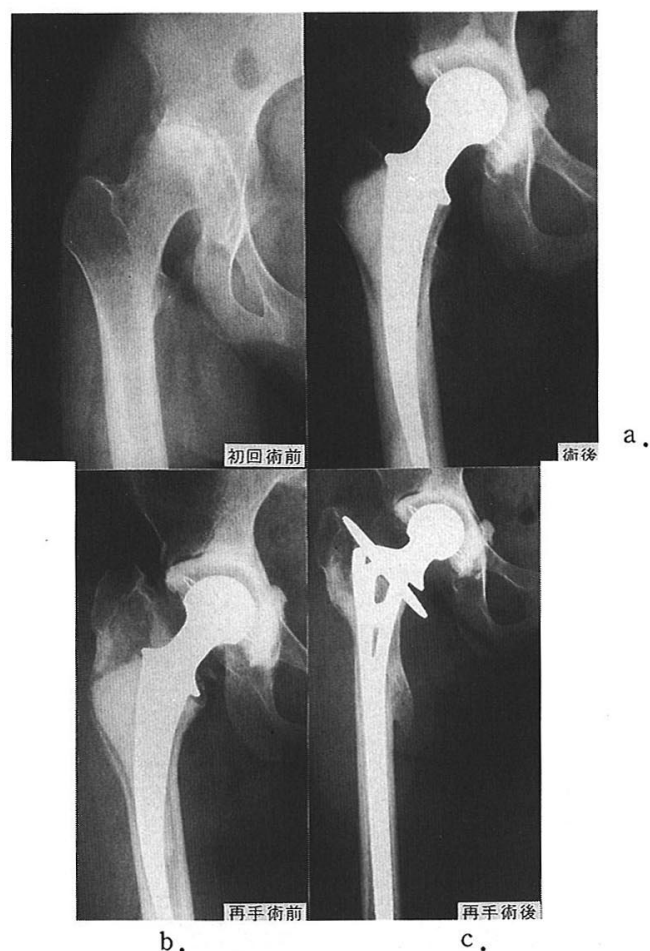

図 3 R.I., 31 才, 女性.

a . cementing, stem の設置にやや難あり

b. 術後 8 年 stem 側の著明な loosening

c 、骨移植併用の上, trochanter plate 使用し, BHP Moore type $の$ long stem に置換

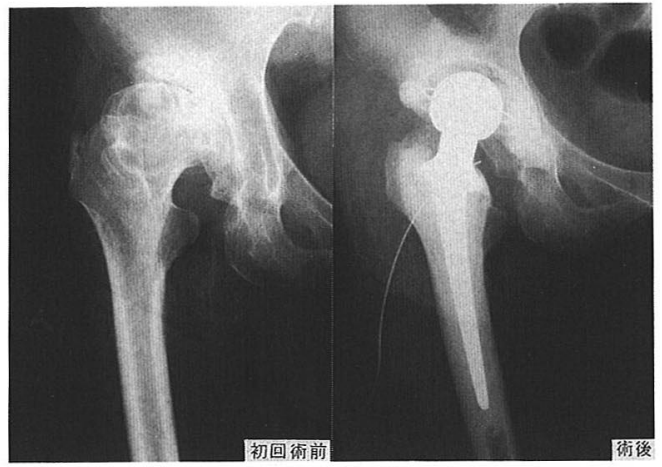

図 4 H. T., 55 才，女性.

績を左右する大きな要因と考えられ2),われわれの症例 においても 10 例中 9 例が緩みによる再手術であった。 とくに stem 側の緩みが多く, 本邦での他の報告 ${ }^{913)}$ と は異なっていた。これは，その原因を考えるに stem 側 での cementing, stemの選択不良という technical failure が主因をなしていたためであろう。また, 肥満,

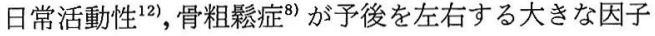
であるとの報告もある。当院でも 2 例経験しており， とくに骨粗鬆症に関しては, 患者自身で control 不能な 性質のものであり, 将来的に大きな課題が残されてい る.さて, 再手術にあたっては, レ線にて全周に進行 性の clear zone が出現し, 明らかな prosthesis の移動

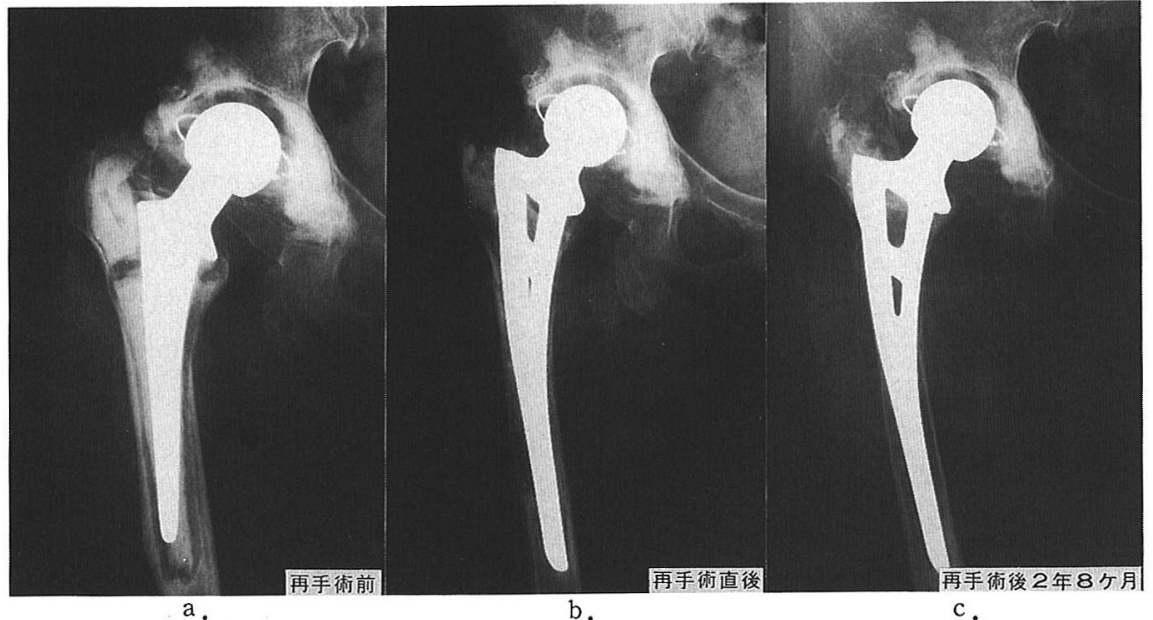

図 5 H. T., 55 才, 女性.

a.術後 4 年 2 力月後, stem 側の著明な loosening と cement の折損あり

b. BHP Moore type stem に置換

c 、stemの沈下および中央部にて著明な骨皮質の菲薄化みられる 


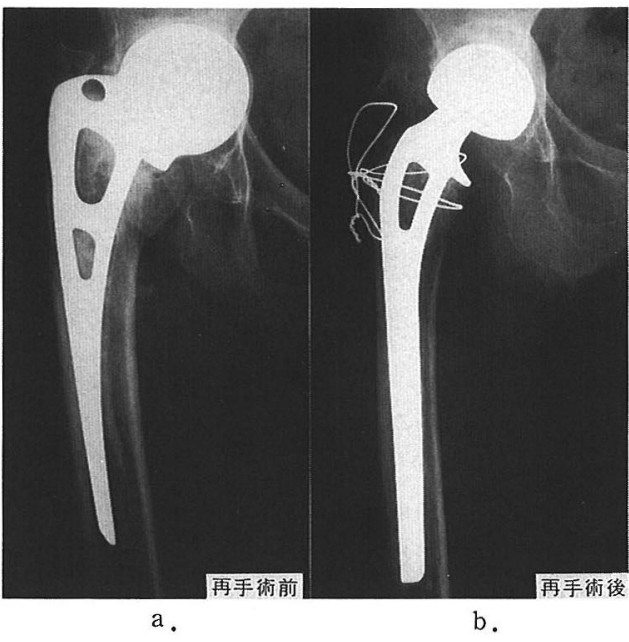

図 6 S. K., 70 才, 女性.

a. central migration あり

b. 白蓋側, stem 側に骨移植併用の上, Osteonics type に置換

があり, 安静時, 回旋時痛にて $\mathrm{ADL}$ 上支障のあるもの を，緩みありと診断し，再手術を行った，再手術の成 績は諸家の報告4)5) をみると, 当然のことながら, 不良 であり,その理由として bone stock が量的質的に劣っ ていること, 合併症の発生率が高くなることなどを挙 げている1).そこでわれわれは, 量的質的に粗悪化した 状態でのセメント使用は将来的に今まで以上の高い緩 みの発生が予想されることにより ${ }^{11}$, 再手術は原則とし て, cementless で骨移植を併用して行った。その merit としては bone stock を増大させ, 骨自体の bone ingrowth を促し direct fixation を期待できる.また, 緩み が生じても再固着が可能という点であるが，問題は長 期の免荷を要すること, stem の沈下夰であろう. stem の沈下はほぼ全例にみられたが，とくに calcar および 転子部での骨吸収の強い症例は著明であり, 初回 THR の骨頭径の関係上，再手術に self locking type stem を使用したが,この type では沈下を防止できない感が あった. trochanter plate, long stem, 可能であれば pressfit typeの使用も一解決法と思われる。 また， cementless の場合の大前提である biocompatibility の ある生体材料, design の開発も急務である7)。一方, socket 側に関しては, 移植骨が軽度圧潰されるものの, 一時期を経ると stable となり Bipolar type で問題ない ようである.人工骨頭の再手術に関しては骨移植併用 ${ }^{3)}$
の上 Bipolar type に置換した。

\section{結語}

1. 昭和 55 年以降, THR 9 例 10 関節, UHR 11 例 11 関節に再手術を行った。

2. 再手術の原因は, 感染の 2 例を除き, THR では Loosening（とくに stem 側の）がUHRでは central migration がほとんどであった。

3. THR Loosening の原因としては, 手術手技, stem の選択不良が主因と考えられた。

4. 再手術は原則としては, cement は使わず骨移植 併用の上 Bipolar type 人工骨頭を使用. 術後経過期間 は短いがほぼ満足すべき結果を得ている。

\section{参 考 文 献}

1) Amstutz, H. C., et al. : Revision of aseptic loose total hip arthroplasties. Clin. Orthop., 170: 21-33, 1982.

2) Harris, W. H. : Revision surgery for failed, nonseptic total hip arthroplasty. Clin Orthop., 170: 820, 1982.

3) Heywood, A.W. B.: Arthroplasty with a solid bone graft for protrusio acetabuli. J. B. J. S., 62-B : 332-336, 1980.

4) Hunter, G. A.,et al.: The results of revision of total hip arthroplasty. J. B. J. S., 61-B : 419-421, 1979.

5) Pellici, P. M., et al. : Revision total hip arthroplasty. Clin. Orthop., 170 : 34-41, 1982.

6) Wroblewoki, B. M.: Revision surgery in total hip arthroplasty. Clin. Orthop. 170: 56-61, 1982.

7）伊丹康人・他：セメントレス人工股関節にもとめら れるもの. 整形外科 Mook. No. 45 : 310-326, 1986.

8）岩崎勝郎： 50 才未満の患者に対するCharnley 型股 関節全置換術の意義と問題点。整形外科 Mook. 45 ： 144-155, 1986.

9）長屋郁郎・他：Charnley-Müllar 型人工股関節．初 期 100 関節の術後 10 年の長期成績について. 別冊整形 外科, $3: 115-126,1983$ 。

10）富田泰次・他：セメントレス人工股関節置換時の臨 床成績。整形外科 Mook. 45：106-121，1986。

11）室田景久：人工股関節における再置換例とその原因 に関する考察ならびに今後の対策. 整形外科 Mook. $45: 168-178,1986$.

12）山室隆夫・他：50才未満の患者に対する人工股関節 置換術。䠦整外, 18:1128-1136, 1983.

13）山室隆夫 : Charnley 型人工股関節の遠隔成績. 別冊 整形外科, $3: 63-70,1983$. 